\title{
THEORETICAL AND METHODOLOGICAL FOUNDATIONS OF CONFLICT MANAGEMENT STUDIES IN TAX LEGAL RELATIONS
}

Larysa V. Chaika

Foreign Language Research and Teaching Center,

the National Academy of Sciences of Ukraine

82 Ukrainska Str., apt. 50, Irpin, Ukraine, 08201

https://orcid.org/0000-0002-7729-337X

l-chayka@irpin.com

Viktoriia V. Chaika

Law Research and Education Institute, University of the State Fiscal Service of Ukraine

83b Ukrainska Str., apt. 54, Irpin, Ukraine, 08201

https://orcid.org/0000-0001-5990-7342

chaykaviktoriya86@gmail.com

\begin{abstract}
This paper discusses the problems of conflicts that may be from time to time initiated and settled in the field tax legal relations. The emphasis is placed on the suggestion that the evolution of scientific concepts of conflict is based on the interdisciplinary approach: the paper concludes on the impossibility of separating the philosophical, social, psycholinguistic and legal aspects of the conflict. Complex and systematic analysis of the „conflict” category using the integrative approach has been performed as part of the research. Differentiated state-of-art approaches to the conflict as a subject of scientific analysis may be classified into two primary groups: 1) the approaches, where the conflict is considered in a narrow specific sense; 2) the approaches where the conflict is studied from interdisciplinary perspective.

It is determined that any conflict is based on certain confrontation that plays a systemically important framework role both for individual types of conflicts, and for different level of scientific conflict studies. Nevertheless, is concluded that the presence of such confrontation only creates prerequisites for possible behaviour, while the interpersonal relations - i.e. the social category - are pivotal for individual choice of specific communicative interaction strategy.
\end{abstract}

The legal nature and attributive properties of tax conflicts are also discussed from the financial law perspective. The paper distinguishes five specific groups of factors that confirm the actual presence of conflict tax legal relations.

The special attention is paid to the tax dispute characterization (as one of the tax conflict development stages) and the remedies available for taxpayer rights protections. In particular, 
the paper discusses the issues of the taxpayer legal self-defense as the guaranty of subjective rights exercise and lawful interests protection in legal relations as a key for prevention of tax conflicts and disputes.

Finally, the reasons are given to substantiate the conclusion that the tax dispute basically comes down to a mechanism of guaranteeing the interested party's subjective rights enforcement and the balance of public and private interests in the field of taxation.

Keywords: conflict, differences, tax conflict, tax dispute, public and private interests.

\section{INTRODUCTION}

The relevance of the paper's subject is based on the use of both conventional scientific approaches to the study of conflict tax relations (such as administrative and judicial procedures of appealing against the actions by tax authorities and collisions of tax legislation provisions with other industry-specific regulations) and more progressive legal theories involving development of optimal tax legal institute model in the modern tax law theory domain. In particular, the latter tendencies include the theory of public and private interest balance in tax law, tax dispute mediation, et cetera. The use of such scientific and methodological methods for development of conceptual foundation of the tax law may become a basic framework for resolution and prevention of tax conflicts as the consequences of interactions between the tax legal relations subjects (taxpayers and tax authorities) under conditions of uncertainty attributed to political, economic and legal factors.

Taxation is an instrument of organized society. Itself a social institution or group of institutions in the broad sense, taxation exists for the service and promotion of other institutions; in and of itself it produces no personal or social utility. Accordingly, the system of taxation rests on the political, economic and social structure and should be fitted to that structure and adapted to achieving the ends and objectives of society (Blough, 1944).

Matuzov N.I. reasonably notes that the domination of state over the individual personality cannot be considered as the rule of law (Matuzov, 1994). Quite the opposite, the state should attempt to maintain the balance between the interest of the state as subject of power enforcing the public interests and the objective private interests of the taxpayers.

In maintaining such balance of public and private interests in relations regulated by the tax law, it is important to proceed from the premise that the tax law provisions related to certain limitations of individual rights and lawful interests provided by the Constitution, should be adequate, proportional, necessary and correlative with the purpose of such limitations recognized by the framework law. It is obvious that, in establishing such limitations, the legislative bodies are not entitled to introduce any regulations that would either violate the basic concepts of specific right or lawful interests, or result in the loss of its actual essence.

It is well-known that the proper implementation of the tax legislation by the taxpayers results in inflow of tax proceeds to the budgetary system of the state, which ensures the proper funding of the socially relevant direction of the state's financial activities, such as healthcare, social security, pension benefits, et cetera, which does not come in conflict 
with own private interests of the individuals, since the taxpayers simultaneously are the citizens consuming the resulting social benefits. Nevertheless, the state should apply its best reasonable efforts in order to develop the tax legislation and its implementation procedures with consideration to such basic taxation principles as fairness, certainty, convenience and cost effectiveness.

Therefore, the complex fiscal policy mechanism is developed in safeguarding of mutual interests of the state and the subjects of entrepreneurial activity standing on the opposite sides of the wealth distribution process. This mechanism allows identification of the interrelation of qualitative changes occurring the public revenue system and the effects of such changes on the business activity level in the country, as well as the extent of social equality and partnership principles implementation as part of the social development.

At the same time, the legal relations are the area with high potential for development of confrontations and differences, therefore, the conflicts between the public state interests and private taxpayer interests often tend to arise. The actual presence of conflictual tax legal relations is evidenced by the following, including, but not limited to: first, by multiple administrative and legal processes between the taxpayers and the tax authorities, as well as other tax process participants (for example, legal agents); second, by the imperfection of the tax legislation, whose gaps result in limitation and even violation of the taxpayer rights in particular, and civil human right and liberties in general ${ }^{1}$; third, by varying level of public legal consciousness and tax culture of the tax relations subjects; fourth, by the inconsistency between the tax legislation concepts and economically efficient taxation conditions; fifth, by the grounds for development of means and remedies for legal coordination of disputable legal relations (both in theoretical studies, and in actual course of law-making law-enforcement activities).

In view of the foregoing, the authors believe that the study of the "conflict" category may allow successful avoidance of many mistakes and difficulties at different stages of exercise of rights, and in particular, in resolution of tax disputes arising from collision between the public and the private interests in the taxation field.

\section{MATERIALS AND METHODS}

Interactions between the subjects resulting in development of potential non-amicable relations currently attract attention of the growing pool of researchers from various humanitarian science field, including not only the lawyers, economists and taxation experts, but also social studies researchers, psychologists and linguists. Therefore, the methodology of this paper is based on the multidisciplinary approach combining the knowledge and results of extensive prior research in field of tax law and linguistics.

1 Following the words by Professor Philip Baker: «Some would say that taxation and human rights is an oxymoron. An oxymoron is, of course, the conjunction of two otherwise apparently irreconcilable concepts. I personally do not believe that taxation and human rights are in any way irreconcilable or conflicting; I think human rights are a fundamental aspect of taxation. Human rights limit what governments can do to their citizens - to people affected by their decisions. I think at the moment we are at a very exciting stage, where we are seeing the extension of human rights principles into the tax field, to provide limits to what governments can do to taxpayers. It is part of the balance between the powers of the state and the rights of taxpayers» (Baker, 2001). 
Furthermore, ontological status of such interactions, in particular in linguistics field, still remains uncertain: there arise many concepts, terms, definitions (see e.g. review by (Leung, 2002)), resulting in terminological confusion (Nelson, 2001), and the research field attracts new concepts of varying scope and contents (disagreement, conflict, dispute, complaint, argument, etc) (Antaki, 1994; Boggs, 1978; Brenneis, 1988; Eisenberg, 1981; Grimshaw, 1990; Kotthoff, 1993; Laforest, 2002; Pomerantz, 1984; Schiffrin, 1985 et al). This results in need to define the concepts, which would characterize the studied type of inter-subject relations in a most complete and accurate manner, identify its categorial features and establish its place in the discourse activity system in order to support the further search of means for avoidance of conflicts in the tax relations field, timely prevention of tax conflicts, early identification and resolution of tax conflicts through legal remedies and settlement of tax conflict negative consequences.

\section{RESULTS AND DISCUSSION}

Negatively characterized relations between two or more subjects are usually associated with conflict - a phenomenon, intrinsically inherently to human being and thinking, which "accompanies humans throughout their entire lives and is reflected and in both incarnations of existence, being concentrated in the internal world and exhibited to the external world" (Yermolaieva, 2005). The presence of "naive" concept of conflict in the consciousness of representatives of different cultural and speech communities, popularity and significance of this scientific concept, however, do not correspond to its clear and unambiguous interpretation. It is obvious that investigation of the conflict verbal manifestation essence may yield any productive results only provided proper employment and use of the clarification potential of humanitarian disciplines offering an insight into the conflict phenomenon.

As part of the everyday life, the conflict is perceived as a wide circle of realities: family argument, military actions, parliamentary discussions, confrontation of internal motives, struggling with own desires and responsibilities, et cetera (Hryshyna, 2002), as well as manifestations of violence regarding of their form (Svietlov, 2003). In the course of a lifetime, any individual inevitably faces the conflict situations and develops his or her conflictological experience - i.e. a certain information about principles, methods and behaviours in preconflict and conflict situations accumulated during one's life and partially inherited from previous generations (Antsupov, 2005). As the studies show (Antsupov, 2008), such empirical individual and collective experience that offers the recipes for optimal conflict situation resolution plays an essential role, since the human behaviour strategies during conflict are determined by the personal life experience by $99 \%$ and by scientific conflict research knowledge only by $1 \%$.

In addition to everyday practice, the knowledge and understanding of conflict to some extent are developed by the coverage of conflict concept in the Bible, the works of literature and art.

It is a well-known fact that the Christianity is the most common religion in the Englishspeaking world, so it is reasonable to believe that the Biblical concepts, where the God acts 
as the absolute incarnation of good, and the Devil acts as the absolute incarnation of evil, significantly contribute to the development of an English-speaking individual world views.

The Christian philosophy calls for resolution of ideological conflicts and strongly condemns possible confrontations and misunderstandings between the people, although the study results reveal the ambiguous perceptions of war and peace, concord and violence, inherent to both Christian and other religious doctrines. In particular, the Bible content analysis show multiple discrepancies in approaches to the "violence - peace" problem solution (Antsupov, 2008). There are also many inconsistences in terms of worldview positions of different Christian cultures and communities, as well as in church attitude toward confrontations and societies, acts of war and violence, that tend to constantly evolve over time.

The works of art brilliantly reflect the original confrontation of good and evil, internal intensions and external factors of human behaviour. Furthermore, the art generally illustrates the concept of conflict in a more comprehensive, diverse, "vivid" and individualized manner than science with consideration to the dialectics of public and personal interests (Tsiurupa, 2004).

The conflict as a phenomenon that plays an essential role in the existence of human individual and the society in general always has found its place in the artistic and imaginary forms of reality representation. Literature, painting, sculpture, music, dance, cinema, theatre, and other forms of art have always artistically reflected the conflicts and influenced the formation of attitudes toward this concept among viewers, readers, and listeners. Since its very inception, the art has been a powerful factor in human spiritual and practical exploration of conflict. Furthermore, the artistic comprehension of reality does not oppose the scientific comprehension of the conflict, but rather supplements, intensifies and facilitates it (Antsupov, 2005).

In recent decades, the role of the mass media as a powerful factor influencing human consciousness and behaviour, including in terms of conflict, has increased dramatically. The constant media coverage of various conflicts also influences the masses in this aspect to a large extent. The results of sociological studies, for example, show that watching informational television programs most often invokes in people the feeling of anxiety, concern, defencelessness, fatigue and insecurity (Antsupov, 2008). Obviously, these feelings influence the human the behaviour in conflict situations.

The scientific tradition of conflict research has a long and extensive history. Due to the universal prevalence of the conflicts, the attempts to comprehend this phenomenon date back to the antiquity. As early as VII-VI centuries B.C., Chinese philosophers believed that the source of the development of all things in the world was the constant confrontation of positive (yang) and negative (yin) sides of matter. The Classical Ancient society developed the first scientific speculations about the role of conflicts in the social environment; the conflict was often identified with the struggle of cosmic forces and was considered inevitable (Tsiurupa, 2004). During the following centuries, the outstanding philosophers of different nations (F. Aquinas, N. Machiavelli, E. Rotterdam, F. Bacon, J. J. Rousseau, I. Kant, etc.) attempted to make sense of the concept of conflict or its individual aspects (see literature review by (Antsupov, 2008; Vashchenko, 2000; Herasina, 2002; Hryshyna, 2002) et al). 
The significant importance is attributed to the opinion expressed in the 17th century by T. Hobbes, who speculated that conflict was a natural condition of society, a human attitude towards others, conditioned by the desire for power, satisfaction of one's own needs, etc. (the concept of "a condition of war of everyone against everyone”) (Hobbes, 1985). An essential component of Hobbes' theory was the recognition of the regulative function of the state in solving the problematic situations. These were exactly the ideas that laid the foundation for modern concepts, where the democratic states have considerable regulatory potential, in contrast to totalitarian ones, where conflicts are resolved in a violent manner.

In the dialectical doctrine by F. Engels, the conflict emerges as a constant driving force; according to the law of unity and struggle of opposites, movement and development are possible only in the presence of confrontation fueling the continuous strive to understand and solve the problems (Frolov, 1980). This view corresponds to the modern philosophical understanding of conflict as a category, and reflects the stage (phase and form) of the confrontation category development, when the opposites that exist in the contradiction turn into extreme opposites (polarity, antagonism), reach the moment of mutual negation of each other and elimination of contradiction (Osypov, 1998).

Besides philosophers, the concept of conflict has attracted attention of many prominent psychologists (Z. Freud, A. Adler, E. Fromm, K. Lorenz, K. Levin, E. Berne and many others), where some of the psychological studies of conflict border on sociological side of research (J. Moreno, A. Bass, W. MacDougal and others). Sociological analysis of conflicts emerged in the XIX century in the works of H. Spencer; a special place in the theory of social conflict is occupied by the works of K. Marx - the forerunner of conflictology, whose materialistic understanding of history enabled a new view of the social relations development. The analysis of the social aspect of conflict received its further development in the works by G. Simmel, T. Parson, L. Koeser, R. Darendorff, C. Boulding and other scholars. Th conflict is also currently regarded as the central problem of social psychology (see more in (Antsupov, 2005; Hryshyna, 2002; Stepanov, 2001; Tsiurupa, 2004, etc.)).

Besides philosophy, psychology, sociology and social psychology, the conflict is also regarded as one of the most important problems studied in political science, history, art history, educational science, legal science, military science, etc. (Antsupov, 2008). At the same time, the research data show (Hryshyna, 2002) that perception of the conflict phenomenon by an ordinary laymen person and a scholar often overlap to a large extent.

The modern approaches to the conflict as the subject of scientific analysis may be broadly divided into two main categories:

- Approaches, where the conflict is considered in a narrow specific meaning;

- Approaches, where the conflict is studied from the interdisciplinary perspective.

As part of the narrow specific approach, only those aspects and levels of the conflict that are relevant to the subject studied in a particular scientific discipline are analyzed and researched in a scientific practice.

In the XX century, especially in the second half of the century, the evolution of scientific conceptions of conflict was primary based on the interdisciplinary approach, where the impossibility of separating the philosophical, social, psychological and legal aspects of conflict was recognized and accepted. On the one hand, this has led to the development of an 
integrative approach to the analysis of conflict in psychology, sociology, social psychology, legal science, and, on the other hand, such perception contributed to the formation of conflictology as an independent science, based on the postulate that any conflict is based on certain confrontation that plays a systemically important framework role both for individual types of conflicts, and for different level of scientific conflict studies science (Herasina, 2002). This assertion confirms the connection of the conflict with the category of confrontation, thus defining the existential feature of conflict, although failing to define the other essential characteristics and the content of this scientific concept.

In particular, by stating that the conflict is a „rubber-like concept” (Nechyporenko, 1982), the conflict scientists abandon its broad interpretation as „a collision of something with something", which is consistent for all existing views, but turns out to be meaningless in the scientific sense (Vasyliuk, 2001). The philosophical postulates within the conflictology are instantiated and projected into the plane of human social communicative practice: "conflictology is a unique interdisciplinary domain that combines <..> approaches to description, study and development of conflict management practices applicable to the different type of conflict phenomena arising in various areas of human interaction" (Hryshyna, 2002).

Nevertheless, if we include anything related to confrontation to the category of conflict, the range of "conflict phenomena” would be too numerous and diverse. Therefore, it is difficult to delineate the boundaries of the conflict subject field, which combines the special psychological state of a person; differences in views, beliefs and values; and the struggle of social groups and individuals to achieve one or more goals. For example, the statement that the "the object of conflictology is the conflicts in general" (Antsupov, 2008) extends to category of conflict to any „acute negative experience caused by a long struggle of the structures of the human external world ..." (Antsupov, 2008), that is, a special psychological state of a person, which may not manifest itself in communication, although at the same time the conflict is characterized as a „pronounced negative experience” Antsupov, 2008).

However, according to the most available definitions (the conflict as „the sharpest way of resolving significant contradictions arising in the process of interaction, consisting in the opposition of the subjects of the conflict, usually against a background of negative emotions" (Antsupov, 2008), „conflict acts as a bipolar phenomenon - the opposition of two principles, and manifests itself in the activity of parties aimed at overcoming contradiction, where the conflict parties are represented by active subject(ts)” (Hryshyna, 2002), „the conflict a clash of oppositely directed goals, interests, positions, opinions of subjects of interaction, i.e. a confrontation between people emerging for the purpose of solution of those or other issues in social and private life” (Bandurka, 1997), „the sharpest way of solving existing or imagined contradictions in the process of human interaction, consisting of the opposition of subjects of conflict and usually accompanied by tension of emotional and volitional sphere" (Tsiurupa, 2004), the conflictology researches focus mainly on studying human behaviour in situations of apparent confrontation. The strategic context of verbal communication within the scope of conflict communication is illustrated by G. Lakoff and M. Johnson as a conceptual metaphor „Argument as War”: „We see the person we are arguing with as an opponent. We attack his positions and we defend our own. We gain and lose ground. We 
plan and use strategies. If we find a position indefensible, we can abandon it and take a new line of attack. Many of the things we do in arguing are practically structured by the concept of war, and thus is carried out in terms of war as a result of the conceptual system of our culture that we have internalized".

In our authors, the greatest importance is attributed to the clarification of the value of interpersonal relations as the leading factor determining the strategy of personality behaviour in a conflict situation (Yemelianov, 2003). The two-dimensional model of personality strategies in conflict interactions, developed by K. Thomas and R. Killman, is widely used in conflictology. This model by Thomas and Killman (based on the focus of the conflict participants on their own interests and the interests of the opposite party), is complemented in the aforesaid paper by the third dimension - the value of interpersonal relations.

This offer an opportunity to argue that if the conflict interaction is characterized by a low degree of focus on the interests of the other party, and a high degree of focus on personal interests with the negative assessment of the interpersonal relations value (Yemelianov, 2003), then the conflict results in "disharmonization of interpersonal relations” (Bandurka, 1997) due to manifestations of hostility by conflict participants. Hostility is considered as having a graded nature: the minimum degree of hostility is manifested in competitiveness behaviour that has a rational in its nature and corresponds to the certain social norms; while the maximum degree of hostility is associated with disregard for social norms, irrational behaviour, the desire not simply to win or secure victory, but rather to suppress, defeat or humiliate the opponent (Filley, 1975).

Therefore, the achievements of conflictological research show that the presence of such confrontation only creates prerequisites for possible behaviour, while the interpersonal relations - i.e. the social category - are pivotal for individual choice of specific communicative interaction strategy.

Tax Conflicts and Their Features. The conflict in law is a type of social conflict, while the tax conflict, in turn, is a type of legal conflicts in general. Their existence is not only subjective, but also objective social phenomenon, because tax conflicts stem from social conflict, the basis of which is the existence of opposing interests: the public and the private (Yefimov, 2018).

The opposite interests of tax legal relations subjects and diversity of objects of tax regulation create potential for tax conflicts with different motivation and character. At the same time, all tax conflicts, as legal phenomena, are characterized by certain common specific features:

1. Parties involved (the parties of a tax conflict represented on the one hand by the taxpayers and tax agents (individuals or legal entities), and on the other hand by the state acting through its tax authorities)

2. Nature of legal relations (the subject of the conflict may only relate to taxes, tax control procedures and challenging of acts or actions by the tax authority representatives);

3. Legal inequality of participants, arising from the relationship of power-subordination, where one party is always a public authority -i.e. a tax authority);

4. Specific legal form (pre-trial / extrajudicial conflict or judicial conflict, which is often called a tax dispute). 
The fourth feature determines the remedies available for rights and legitimate interests of the taxpayers.

Tax Disputes and Taxpayer Rights Protection Remedies. It is well-known that the most important sign of democratic development of society and the nation as a whole is not only the presence of legally defined remedies for protection the rights, freedoms and legitimate interests of an individual (person or citizen), but also a guaranteed possibility of their exercise and actual enforcement. Therefore, modern national systems for protection of rights and legitimate interests of taxpayers include two forms - jurisdictional and non-jurisdictional. In turn, in Ukraine, the jurisdictional form involves two types of remedies - judicial and administrative, while the non-jurisdictional form preferably includes the remedies of legal self-defense.

The authors see the positive trend in the fact that para. 56.1 art. 56 of the Tax Code of Ukraine (the Tax Code of Ukraine, 2010) provides the taxpayer with choice of alternative methods of appealing against decisions taken by the tax control authority: i.e. administrative or judicial. In other words, in Ukraine, the pre-trial procedure for resolving tax disputes is not mandatory. In this connection, the taxpayers who believe that their rights as in capacity of participants of the tax process, have been violated, have a legal right to immediately apply to court bypassing the stage of administrative appeal.

The very notion of "alternative”, which is understood as an ability to choose one of a number of possible options, contains an element of discretion and variability, which is an inherent feature of progressively oriented social formations. This approach to resolving tax disputes contributes to the development of manifestations of diversity of behavioural algorithms of tax law subjects, and, as a consequence, to the enforcement of their subjective procedural rights.

Many countries are interested in implementing mediation as an alternative dispute resolution in order to deal with tax controversies. The most common reason for countries to implement mediation is to address an excessive and increasing volume of tax appeals, which jeopardize the legal protection of taxpayers (van Hout, 2018).

At the same time, unfortunately, Ukrainian tax legislation has not yet introduced the institution of tax dispute mediation in tax disputes, despite some progress towards solving this problem and the positive experience of implementation of such an institution in some EU countries, such as the UK, the Netherlands, Belgium, etc.

The modern system of Ukrainian taxpayer rights and legitimate interest protection includes two distinct types of remedies - jurisdictional and non-jurisdictional. The jurisdictional remedies available for protection of taxpayer rights and legitimate interest should be understood as a procedural form of exercise of the taxpayers' material rights to protection defined by law, and by the methods of protection of rights and legitimate interests of taxpayers - specific lawful measures aimed at elimination of violation of rights or actual threat of such violation and influence on the offender.

In turn, the jurisdictional form involves two types of remedies - judicial and administrative, while the non-jurisdictional form preferably includes the remedies of legal self-defense. The judicial remedies provide the possibility for protection of the taxpayers' rights and legitimate interests before the national courts (the Constitutional Court of Ukraine and the system of 
administrative courts) and international courts (in particular, the European Court of Human Rights). The administrative remedies include the possibility for protection of the taxpayers' rights and legitimate interests before the bodies of the State Fiscal Service of Ukraine and other state authorities. Other state authorities in this case include the Ombudsman of the Verkhovna Rada of Ukraine and the Business Ombudsman Council, which is an advisory body under the Cabinet of Ministers of Ukraine. The self-defense remedies are based on the concept of self-regulation and the choice of the behavioural strategy by the taxpayers, whose goal is to protect their rights and legitimate interests in the field of taxation. Such remedies consist in the implementation by an affected person of any countermeasures that are not prohibited by applicable law and do not contradict the moral foundations of the society.

Despite the extensive pool of both domestic and foreign publications dedicated to the problems of the taxpayers' rights protection under administrative and judicial procedures, here, the authors would like to elaborate on the remedies of legal self-defense as a way to protect the rights and interests of taxpayers.

The essence of legal self-defense lies in the fact that the appropriate lawful remedies of protection may be applied by a taxpayer on its own, without recourse to jurisdictional bodies, according to the procedure strictly defined by law. To put it in other way, the legal self-defense consists of the actual actions aimed at the prevention of mitigation of negative consequences of violation of the rights and legitimate interests of a taxpayer, where the latter performs such actions without recourse to a court or other public authority, authorized to consider a tax dispute.

In the opinion of authors, the legal self-defense may manifest itself both as action or as failure to act by the taxpayer. Relying on such interpretation, the authors distinguish two types of legal self-defense - i.e. active-defensive form and preventive form.

In particular, the active-defensive form includes installation of video surveillance cameras in the taxpayer's premises and audio or video recording (for example, using a camera or mobile device) of the actions by officials of the Stare Fiscal Service of Ukraine bodies during the field tax audit, which disciplines controllers in a certain way and leaves them no choice but to act in strictly defined legal procedural framework. Such right is provided to the taxpayers in compliance with the para. 8, part 4 of the Law of Ukraine on Fundamental Principles of State Supervision (Control) of Economic Activity (Law of Ukraine on Fundamental Principles of State Supervision (Control) of Economic Activity, 2007), which directly states that the state supervision (control) authorities and business entities are entitled to record the process of both scheduled and unscheduled activities or each individual action using the audio- and video recording equipment without interfering with the course performance of such control activities.

At the same time, when using this remedy, the taxpayer should remember that the audio and video recording of actions by the officials and/or officers of the Fiscal Service of Ukraine during the tax audits is possible only with their consent and within the limits of the data privacy and collection legislation. The legal basis for the tax audit procedures are provided by the Tax Code of Ukraine.

Furthermore, due to its legal nature, the audio and video recording of actions by supervision authorities is basically qualified as collection, receipt and creation of information about their 
activities. Such legal relations in Ukraine are regulated by both national and international legislative provisions, including, but not limited to the Convention for the Protection of Human Rights and Fundamental Freedoms, the Constitution of Ukraine (art. 32 and 34) (Constitution of Ukraine, 1996), the Civil Code of Ukraine (para. 2, part 1, art. 302; para. 1, art. 307) (Civil Code of Ukraine, 2003), the Law of Ukraine on Information (part 1, par. 2, art.5) (Law of Ukraine on Information", 1992), and the Law of Ukraine on Access to Public Information (Law of Ukraine on Access to Public Information", 2011).

Following the comprehensive legal analysis of the above-mentioned legislative provisions, it is possible to highlight another problem: on the one hand, the on Fundamental Principles of State Supervision (Control) of Economic Activity provides the audited entity a right to create the video recordings of actions by the officials and officers of the public authorities, while, on the other hand, collection, storage and dissemination of information about a person without his or her consent is directly prohibited by the Article 32 of the Constitution (the Constitution of Ukraine, 1996) and Article 302 of the Civil Code (Civil Code of Ukraine, 2003).

However, the authors believe, there is a certain caveat to this situation in the current legislation, and namely in compliance with the para. 2, art. 5 of the Law of Ukraine on Personal Data Privacy (Law of Ukraine on Personal Data Privacy, 2010), any personal data of a person holding a position related to the exercise of state or local self-government functions, official or public powers shall not be treated as confidential information. Also, according to the part 1 of the Decision of the Constitutional Court of Ukraine dated 20.01.2012. № 2-rp / 2012 on the case № 1-9 / 2012 ,the information about private and family life of a person shall include any information and / or data on proprietary and non-proprietary relations, circumstances, events, relationships, etc., associated with the person and his family members, except for the information, provided by law, which relates to any person holding a position related to the exercise of state or local self-government functions, official or public powers. Such information about a person shall be deemed confidential" (Decision of the Constitutional Court of Ukraine, 2012).

Based on the above, it is possible to draw a conclusion that the collection of information (in particular, recording of control activities by of officials and / or officers during a tax audit) is carried out in connection with the performance of official or official powers by such persons and relates to performance of public functions, this cannot be qualified as the collection of confidential information (in particular, information about private and family life or personal data) of individual.

However, in order to avoid multiple and ambiguous interpretations of the content of rights provided to audited and auditing entities, as well as to prevent limitation the taxpayer's rights during tax audits, the authors consider it advisable to amend the Tax Code of Ukraine and include a direct provision that authorizes the taxpayers to perform audio and video recording of actions by the officials of supervision authorities during tax audits.

Preventive form of legal self-defense in tax legal relations, as viewed by the authors, includes, but is not limited to refusal to perform certain actions. This remedy is not directly reflected in tax legislation. At the same time, the possibility of refusal from fulfillment of illegal requirements by public authorities as a remedy of legal self-defense is provided by 
the Article 19 of the Constitution of Ukraine (the Constitution of Ukraine, 1996), according to which no citizen shall be forced to do commit any actions, not provided by the legislation.

An example of application of such legal self-defense remedy is denial of access for officials of the supervision authorities to the audited facility due to violation of the procedure and improper grounds for appointment of tax audit (e.g. performance by supervision authorities of scheduled tax audit more often than prescribed by the Tax Code of Ukraine and / or failure to give written notification specifying the dates of the tax audit date commencement and completion). This means even at the early stage of granting access for performance of the tax audit, the taxpayers are entitled to claim invalidity of the tax audit appointment and performance and exercise their rights for protection against unreasonable and unfounded implementation of tax control in respect of their activities. However, according to the judicial court practice (in particular, according to the Decision by the Supreme Court of Ukraine dated 24.12.2010. No. 21-25a10 (Decision by the Supreme Court of Ukraine, 2010), voluntary granting access to the audit supersedes and voids the legal consequences of procedural violations committed by the supervision authority at the stage of the tax audit appointment.

Therefore, the taxpayers that have the reasons to suspect the violation of procedures and grounds for appointment of the tax audit in their regard, may protect their rights by denial of access to the officials of the regulatory authorities for performance of the allegedly improper tax audit. Nevertheless, if the public officials are granted access for performance of the tax audits, then subsequently the court hearing of appeal may cover only the merits of identified violations of tax and other applicable legislation, compliance with which is controlled by the supervisory authorities.

Consequently, essence of legal self-defense lies in the fact that the appropriate lawful remedies of protection may be applied by a taxpayer on its own, without recourse to jurisdictional bodies, according to the procedure strictly defined by law. To put it in other way, the legal self-defense consists of the actual actions aimed at the prevention of mitigation of negative consequences of violation of the rights and legitimate interests of a taxpayer, where the latter performs such actions without recourse to a court or other public authority, authorized to consider a tax dispute.

Based on the interpretation the legal self-defense the taxpayer's rights may be exercised both in the form of action and failure to act, it is possible to distinguish two types of legal selfdefense remedies - active-defensive, which involves the implementation of active actions to protect the taxpayer's rights and legitimate interests, and preventive, which in particular may involve refusal to perform certain actions not provided for by tax legislation and may be associated with illegal, unfounded or baseless requirements by the supervision authorities.

\section{CONCLUSIONS}

Legal relations arising between public and private entities in course of financial activities of the state are of multidimensional nature and inherently have high potential for arising of conflicts due to their specific social, political and legal content are a priori conflicting. It has been established that any such conflicts are primary based on the confrontation between public and private property interests. 
The desire of a public authority to appropriate financial resources of a private entity contrary to its wishes - in order to implement and enforce the public-legal interests becomes a consequence of objectively existing confrontation between the interests of public and private subjects.

The demands by the public authorities are counterbalanced by the taxpayers' subjective right - the right of ownership, which mediates the enforcement of the taxpayers' legitimate interest - the interest of possession, use and disposal of their property. Management of such conflict is possible through the legalization of financial claims of public authorities on the basis of legislative consolidation of strictly defined conditions, grounds and procedure for the collection of funds from individuals. However, it is obvious that the material law, given the objective and subjective reasons of development of society, the influence of the human factor and other reasons, may contain (and often contains) gaps, which objectively cannot be addressed by the law-makers.

Given this, a tax conflict creates a basis for the transition of a controversy to another stage, which is characterized by the emergence of different initial positions of the parties in the legal assessment of the content of disputed tax legislative provisions and, accordingly, the scope of subjective rights and obligations. Contradiction arising in this case forms the basis for the emergence of a tax dispute, as it requires a solution, the implementation of which is impossible without recourse to the competent authorities of the state.

Therefore, a contradiction arising between public and private parties of tax legal relations, can be considered as a tax conflict, until one of the subjects of such a conflict officially applies for its solution to a jurisdictional body. In other words, a tax dispute is a certain stage in the development of a controversy in the sphere of tax legal relations, or, more precisely, one of its stages - the stage aimed at resolving the controversy. Furthermore, the appeals by the involved party to the jurisdictional body are intended not only to eliminate contradiction occurred, but also to protect subjective rights and secure guarantees for their enforcement.

Consequently, it can be argued that a tax dispute is a mechanism to guarantee the enforcement of subjective rights of affected parties and maintain the balance of public and private interests, because: 1 it is aimed at the protection and restoration of the violated (disputed) right, as well as the prevention of possible violations in the future; 2 it is aimed at resolving the tax conflict arising within the context of enforcement of rights and performance of duties; 3 it is aimed at ensuring the stability of conditions for the implementation of a legal provisions and optimization of legal regulations; 4 consideration of the dispute by the authorized public authorities ensures the stability of the legal system of society.

In fact, the concept of „dispute” in the legal science and its specific features are directly conditioned by the nature of material legal relations, within the framework of which a particular dispute arises. Tax legal relations are relations of the property nature, in the first place. In this sense, a tax dispute combines features of both administrative-law dispute, in which a jurisdictional body verifies the legality of acts and actions by public authorities, and private-law dispute, in which the competent authority, based on the evidence provided by the parties in the dispute, provides legal assessment of those or other circumstances of disputed material legal relations, determines the presence or absence of certain rights and conditions for their implementation. 
In this regard, a tax dispute can be considered as a tax conflict of the subjects of tax legal relations, referred to an authorized jurisdictional body, concerning their mutual rights and obligations, as well as the conditions of their enforcement, and which requires a solution based on a legal assessment of the actual circumstances and verification of the legality of actions of an authority entity in respect of a taxpayer.

Thus, legal mechanisms for resolving tax conflicts are the most effective in the sense that they contribute to overcoming conflicts of tax legislation and other related sectors, stabilize the situation, generate actually defined certain legal, social and economic consequences for the parties to the conflict, as well as guarantee the enforcement of the decision by the governmental or international authorities.

\section{REFERENCES}

Antaki, C. (1994). Explaining and Arguing: the Social Organization of Accounts, London, Thousand Oaks, Calif:: Sage Publications.

Antsupov, A. Y. \& Baklanosvkiy, S. V. (2005). Conflictology with Diagram and Comments, Saint Petersburg:

Piter, $288 \mathrm{p}$.

Antsupov, A. Y. \& Shipilov, A. I. (2008). Conflictology, Saint Petersburg: Piter, 490 p.

Baker, P. (2001). Taxation and Human Rights. GITC Review 1(1), 1-13.

http://taxbar.com/wp-content/uploads/2016/01/gitc_review_v1_n1.pdf

Bandurka, A. M. \& Druz, B. A. (1997). Conflictology, Kharkiv: Fortuna-press, 356 p.

Blough, R. (1944). Conflict and Harmony in Taxation. Retrieved from https://www.jstor.org/stable/985185

Boggs, S. T. (1978). The development of verbal disputing in part-Hawaiian children. Language in Society,

7(3), 325-344. https://doi.org/10.1017/S0047404500005753

Brenneis, D. (1988). Language and disputing. Annual Review of Anthropology, 17, 221-237. https://doi. org/10.1146/annurev.an.17.100188.001253

Eisenberg, A. R. \& Garvey, C. (1981). Children's use of verbal strategies in resolving conflicts. Discourse

Processes, 4, 149-170. https://doi.org/10.1080/01638538109544512

Filley, A. (1975). Interpersonal Conflict Resolution, Glenview: Scott, Foresman.

Grimshaw, A. D. (1990). Conflict Talk: Sociolinguistic Investigations of Arguments in Conversations,

Cambridge: Cambridge University Press.

Herasina, L. M., Panov, M. I. \& Osipova, M.I. (2002). Conflictology, Kharkiv: Law, 256 p.

Hobbes, T. (1985). Leviathan, London: Penguin Books.

Hryshyna, N. V. (2002). Psychology of Conflict, Piter, 464 p.

Kotthoff, H. (1993). Disagreement and concession in disputes: on the context sensitivity of preference structures. Language in Society, 22, 193-216. https://doi.org/10.1017/S0047404500017103

Laforest, M. (2002). Scenes of family life: complaining in everyday conversation. Journal of Pragmatics,

34(10-11), 1595-1620. https://doi.org/10.1016/S0378-2166(02)00077-2

Leung, S. (2002). A Discourse Analytical Perspective. Working Papers in TESOL \& Applied Linguistics, 1(2),

1-19. https://doi.org/10.7916/D8FB52F2

Matuzov, N. I. (1994). More on individual sovereignty. Legal Science, 4, 3-14.

Nechyporenko, L. A. (1982). Bourgeois Sociology of Conflict, Moscow: Politizdat, 142 p.

Nelson, C. K. (2001). If it sounds too good to be true, it is: A Wittgensteinian approach to the conflict

literature. Language and Communication, 21(1), 1-22. https://doi.org/10.1016/S0271-5309(00)00013-6

Pomerantz, A. (1984). Agreeing and disagreeing with assessments: Some features of preferred/ dispreferred turn shapes. In: J. M. Atkinson \& J. Heritage (Eds.), Structure of social action: Studies in conversation analysis (pp. 57-101). Cambridge: Cambridge University Press. https://doi.org/10.1017/ CB09780511665868

Schiffrin, D. (1985). Everyday argument: The organization of diversity in talk. In: T. A. Van Dijk (Ed.), Handbook of Discourse Analysis, 3 (pp. 35-46). London: Academic Press.

Svetlov, V.A. (2001). Conflict Analytics, Saint Petersburg: LLC "Rostok", 512 p. 
Taxlink. All About Taxes. (2010). Resolution by the Supreme Court of Ukraine dated December 24, 2010, judicial court case № 21-25a10. Retrieved from https://taxlink.ua/ua/court/postanova-verhovnogo-suduukraini-vid-24122010-roku-21-25a10/

Tsiurupa, M. V. (2004). Fundamentals of Conflictology and Negotiations Theory, Kyiv: Kondor, 172 p.

Van Hout, D. (2018). Is Mediation the Panacea to the Profusion of Tax Disputes? World Tax Journal, 10(1), 43-97.

Vashchenko, I. V., Girenko, S.P. \& Khamlyan, R. A. (2000). General Conflictology, Kharkiv: Model Vselennoy, $512 \mathrm{p}$.

Vasyliuk, F. E. (2001). Conflict. In: N. V. Gryshyna (Ed.), Psychology of Conflict (pp. 275-277). Piter.

Verkhovna Rada of Ukraine. Legislation of Ukraine. (1992). Law of Ukraine on Information dated October

2, 1992 № 2657-XII. Retrieved from https://zakon.rada.gov.ua/laws/show/en/2657-12\#Text

Verkhovna Rada of Ukraine. Legislation of Ukraine. (1996). Constitution of Ukraine dated June 28,

1996 № 254к/96-BP. Retrieved from https://zakon.rada.gov.ua/laws/show/en/254\%D0\%BA/96-

$\%$ D0\%B2\%D1\%80\#Text

Verkhovna Rada of Ukraine. Legislation of Ukraine. (2003). Civil Code of Ukraine dated January 16, 2003 № 435-IV. Retrieved from https://zakon.rada.gov.ua/laws/show/en/435-15\#Text

Verkhovna Rada of Ukraine. Legislation of Ukraine. (2007). Law of Ukraine on the Main Principles of State Supervision (Oversight) in the Area of Commercial Activity dated April 5, 2007 № 877-V. Retrieved from https://zakon.rada.gov.ua/laws/show/en/877-16\#Text

Verkhovna Rada of Ukraine. Legislation of Ukraine. (2010). Law of Ukraine on Protection of Personal Data dated June 1, 2010 № 2297-VI. Retrieved from https://zakon.rada.gov.ua/laws/show/2297-17/ card2?lang=en

Verkhovna Rada of Ukraine. Legislation of Ukraine. (2010). Tax Code of Ukraine dated December 2, 2010 № 2755-VI. Retrieved from https://zakon.rada.gov.ua/laws/show/en/2755-17\#Text

Verkhovna Rada of Ukraine. Legislation of Ukraine. (2011). Law of Ukraine on Access to Public Information dated January 13, 2011 № 2939-VI. Retrieved from https://zakon.rada.gov.ua/laws/show/en/2939-17\#Text

Verkhovna Rada of Ukraine. Legislation of Ukraine. (2012). Decision of the Constitutional Court of Ukraine dated January 20, 2012, judicial court case № 2-рп/2012. Retrieved from https://zakon.rada.gov.ua/laws/ show/en/v002p710-12\#Text

Yefimov, O. (2018). Tax Conflict by the Example of Allocation. Recht der Osteuropäischen Staaten (ReOS), 3, 86-97.

Yemelianov, S. M. (2003). Practical Course of Conflictology, Saint Petersburg: Piter, 400 p.

Yermolaieva, E. N. (2005) The concept of CONFLICT and its objectivation in lexical and semantic space of modern English language. PhD Thesis. Irkutsk: Kemerovo State University, 212 p. 